\title{
Thermal Processing of Coal in the Plasma Pulverized- Coal Burner
}

\section{SERGEY LUBSANOVICH BUYANTUEV ${ }^{1 *}$, STANISLAV YURIEVICH SHISHULKIN², GENNADY BORISOVICH ZONKHOEV ${ }^{1}$, IVAN VASILIEVICH STARINSKY ${ }^{1}$, ANATOLY SERGEEVICH KONDRATENKO ${ }^{2}$, ANDREY BORISOVICH KHMELEV ${ }^{1}$ and ANATOLY DMITRIEVICH ALFEROV ${ }^{1}$}

\author{
${ }^{1}$ East-Siberian State University of technologies and management, \\ 670013, Ulan-Ude, st. Kluchevskaya, 40v, Russia. \\ ${ }^{2}$ Buryat State University, 670000, Ulan-Ude, st. Smolin's, 24a, Russia. \\ ${ }^{*}$ Corresponding author E-mail: sl.buyantuev@mail.ru \\ http://dx.doi.org/10.13005/ojc/330422
}

(Received: May 23, 2017; Accepted: June 22, 2017)

\begin{abstract}
The article presents a description of the plasma pulverized-coal burner developed in a scientific laboratory "of plasma and plasma technologies physics" for the ignition of pulverized coal stream using the low-temperature plasma, key results of the calculations under the programs "Terra" and "Plazmaugol", results of experimental investigations and test results of the burner prototypes on a heating boiler. Plasma pulverized-coal burner is built under the non-scroll principle and is used to replace mazut in the technological process for the energy of the low-temperature plasma generated in the plasmatron. The non-scroll principle is implemented in the burner through the airand-fuel mixture is supplied tangentially to the longitudinal axis of the burner. Thereby the supplied in such a way pulverized coal blend is twisting and spiraling without using special devices such as a scroll. The replacement of mazut is carried out because of the partial gasification and heating up to a temperature of the self-ignition of the pulverized coal flow. When going out from the burner the flow is mixing with the secondary air and then is ignited. However the released calorific energy is sufficient to maintain the pulverized coal blend flame combustion and the boiler unit kindling.
\end{abstract}

Keywords: plasmatron, pulverized-coal burner, mazut, boiler, coal, the low-temperature plasma, kindling of a bolier.

\section{INTRODUCTION}

Current trends of industry and economy development dictate their own rules the main of which is the efficient and economical use of fuel and energy resources including for the production of calorific and electric energy. It will enhance the economic growth of a separate enterprise and the industry in general. 
The main enterprises producing electrical energy are thermal power stations which are running on solid fossil fuel - coal. These stations are reliable and easy to use. The increasing of the produced electricity final cost is influenced not only by the quality of coal but also by the quantity of boilers kindling. It is important because mazut is used as a start-up fuel. Mazut is also used to flame pulverized coal blend when the blend in the boiler is starting to pulsate for various reasons and the temperature begins to decline sharply so then it can go out.

Apart from mazut inflammation low temperature and its high calorific value there is a number of disadvantages. It should be mentioned such disadvantages as the need for extra energy consumption to maintain mazut in the liquid state especially in winter; the negative impact of sulfur contained in mazut released in large quantities when it is burned on the main and auxiliary boiler equipments; increase of SOx emissions to the atmosphere. These disadvantages indicate the need for full or partial replacement of mazut to alternative sources of additional energy for highlighting the blend and kindling a boiler.

\section{The Description OfThe Device And The Principle Of Its Operation}

We propose to use a variant of the plasmafuel system developed by us as one of the alternative technologies to replace mazut in large power boilers. Let's consider the main advantages of such systems on the example of the plasma pulverized-coal burner shown in Figures 1 and $2^{1}$.

The plasma pulverized-coal burner (fig.1) is composed by two concentric and coaxially arranged tubes of different diameters, the inner tube 1 of the first stage and the outer pipe 2 of the second stage with the fixed electric arc plasmatron 4 in the butt end of the inner tube 1. The burner is provided with two separate adjustable air supply ducts: one - for supplying additional air into the inner tube 1 of the first stage, the second - for supplying additional air into the outer tube 2 of the second stage. Wherein the ducts for supplying air and fuel mixture and air are made in the form of tubes 6 and 7 with the tangential entry which are arranged perpendicularly to the concentric tubes: to the inner tube 1 and the outer tube 2. At the exit of the feeders 10 and 11 are installed dampers 18 and 19 for adjusting the air and fuel mixture consumption. The electric arc plasmatron 4 is installed along the horizontal axis of the inner tube 1 . The power supply of the electric arc plasmatron 4 is provided from the source 23 on the power cables 24 and 25.

The power supply source 23 is a thyristor three-phase converter (rectifier) of AC to DC. Positive output of the source 23 via a cable 24 is connected with the plasmatron and the output with a minus sign - is connected with the plasmatron cable 25 .

The plasma pulverized-coal burner is started as follows. The voltage is supplied from the power supply source 23 through the power cables 24 and 25 to the electric plasmatron 4 . As a result in the plasmatron 4 the electric arc plasma is burnt up which unwinds and is blown into the inner tube 1 by air. The plasma torch 5 is formed at the output from the plasmatron 4 . The pulverized coal from the feeder 10 is supplied to the first stage to the tube 1. The air and fuel mixture consumption supplied to the first stage is $20-40 \%$ of the total air and fuel mixture prepared in the burner. The pulverized coal is injected tangentially twisting spirally in the inner wall of the tube 1 and comes to the plasma torch

Table 1: The coal characteristics from the Tugnuiskiy coal-mining field

\begin{tabular}{ll}
\hline The coal organic matter, \% & \\
\hline $\mathrm{C}^{c}$ & 67,3 \\
$\mathrm{O}^{c}$ & 8,9 \\
$\mathrm{H}^{\mathrm{c}}$ & 3,3 \\
$\mathrm{~N}^{\mathrm{c}}$ & 0,7 \\
$\mathrm{~S}^{\mathrm{c}}$ & 0,4 \\
$\mathrm{The} \mathrm{coal} \mathrm{mineral} \mathrm{matter, \%}$ & \\
$\mathrm{SiO}_{2}$ & 11,33 \\
$\mathrm{TiO}_{2}$ & 0,66 \\
$\mathrm{Al}_{2} \mathrm{O}_{3}$ & 2,27 \\
$\mathrm{Fe}_{2} \mathrm{O}_{3}$ & 2 \\
$\mathrm{CaO}$ & 1,53 \\
$\mathrm{MgO}^{\mathrm{K}_{2} \mathrm{O}}$ & 0,68 \\
$\mathrm{Na}_{2} \mathrm{O}$ & 0,48 \\
$\mathrm{~W}^{\mathrm{p}}$ & 0,48 \\
$\mathrm{~A}^{\delta}$ & 14 \\
$\mathrm{~V}^{\mathrm{r}}$ & 19,4 \\
$\mathrm{Q}_{\mathrm{H}}^{\mathrm{P}}, \mathrm{kJ} / \mathrm{kg}$ & 45 \\
\hline
\end{tabular}


Table 2: Dynamics of changes in the concentrations of oxygen, nitrogen oxides, carbon monoxide in the exhaust gases and in the content of fuel remnants in the ash and the slag when testing plasma burners

\begin{tabular}{|c|c|c|c|}
\hline & $\begin{array}{l}\text { The plasmatron is } \\
\text { switched off }\end{array}$ & $\begin{array}{l}\text { The content } \mathrm{O}_{2}, \% \\
\text { The plasmatron is } \\
\text { started up }\end{array}$ & The change, $\%$ \\
\hline \multirow[t]{4}{*}{1 sample } & 8 & 8,1 & \\
\hline & 7,8 & 8,2 & \\
\hline & 8 & 8,1 & \\
\hline & 7,93 & 8,13 & $-2,52$ \\
\hline \multirow[t]{4}{*}{2 sample } & 8 & 7,8 & \\
\hline & 7,8 & 8,3 & \\
\hline & 8 & 8,2 & \\
\hline & 7,93 & 8,1 & $-2,1$ \\
\hline \multirow[t]{7}{*}{3 sample } & 8,7 & 8,2 & \\
\hline & 8,5 & 8,4 & \\
\hline & 8,2 & 8,3 & \\
\hline & 8,47 & 8,3 & 1,97 \\
\hline & The average value 2 & $\%$ (value $1,97 \%$ exclu & \\
\hline & & The content $\mathrm{CO}, \mathrm{M}$ & \\
\hline & $\begin{array}{l}\text {-The plasmatron is } \\
\text { switched off }\end{array}$ & $\begin{array}{l}\text { The plasmatron is } \\
\text { started up }\end{array}$ & The change, $\%$ \\
\hline \multirow[t]{4}{*}{1 sample } & 18 & 8 & \\
\hline & 17 & 10 & \\
\hline & 19 & 10 & \\
\hline & 18 & 9,33 & 48,15 \\
\hline \multirow[t]{4}{*}{2 sample } & 14 & 11 & \\
\hline & 15 & 11 & \\
\hline & 17 & 11 & \\
\hline & 15,33 & 11 & 28,26 \\
\hline \multirow[t]{7}{*}{3 sample } & 15 & 13 & \\
\hline & 17 & 13 & \\
\hline & 18 & 12 & \\
\hline & 16,67 & 12,67 & 24 \\
\hline & The average value 3 & & \\
\hline & & The content $\mathrm{NO}_{\mathrm{x}}, \mathrm{N}$ & \\
\hline & $\begin{array}{l}\text {-The plasmatron is } \\
\text { switched off }\end{array}$ & $\begin{array}{l}\text { The plasmatron } \\
\text { is started up }\end{array}$ & The change, $\%$ \\
\hline \multirow[t]{4}{*}{1 sample } & 656 & 551 & \\
\hline & 648 & 548 & \\
\hline & 684 & 571 & \\
\hline & 662,67 & 556,67 & 16 \\
\hline \multirow[t]{4}{*}{2 sample } & 606 & 558 & \\
\hline & 618 & 562 & \\
\hline & 594 & 572 & \\
\hline & 606 & 564 & 6,93 \\
\hline \multirow[t]{2}{*}{3 sample } & 630 & 562 & \\
\hline & 618 & 583 & \\
\hline
\end{tabular}




$\begin{array}{llcl} & \begin{array}{l}595 \\ 614,33\end{array} & \begin{array}{l}561 \\ 568,67\end{array} & 7,43 \\ \text { The average value } \begin{array}{l}10,2 \% \\ \text { The fuel remnants in the ash and the slag } \\ \text { In the ash, \% } \\ 6,5\end{array} & \begin{array}{l}\text { In the slag, \% } \\ 20,9\end{array} & 14,8 \\ \begin{array}{l}\text { The plasmatron is } \\ \text { switched off }\end{array} & 1420 & 3,4 & 7,8 \\ \begin{array}{l}\text { The plasmatron is } \\ \text { started up }\end{array} & 1440 & 4,8 & 17,5 \\ \begin{array}{l}\text { The plasmatron is } \\ \text { switched off }\end{array} & 1505 & 2,9 & 17,1 \\ \begin{array}{l}\text { The plasmatron is } \\ \text { started up }\end{array} & 1530 & 2,9 & \\ \begin{array}{l}\text { The plasmatron is } \\ \text { started up }\end{array} & 1620 & & \end{array}$

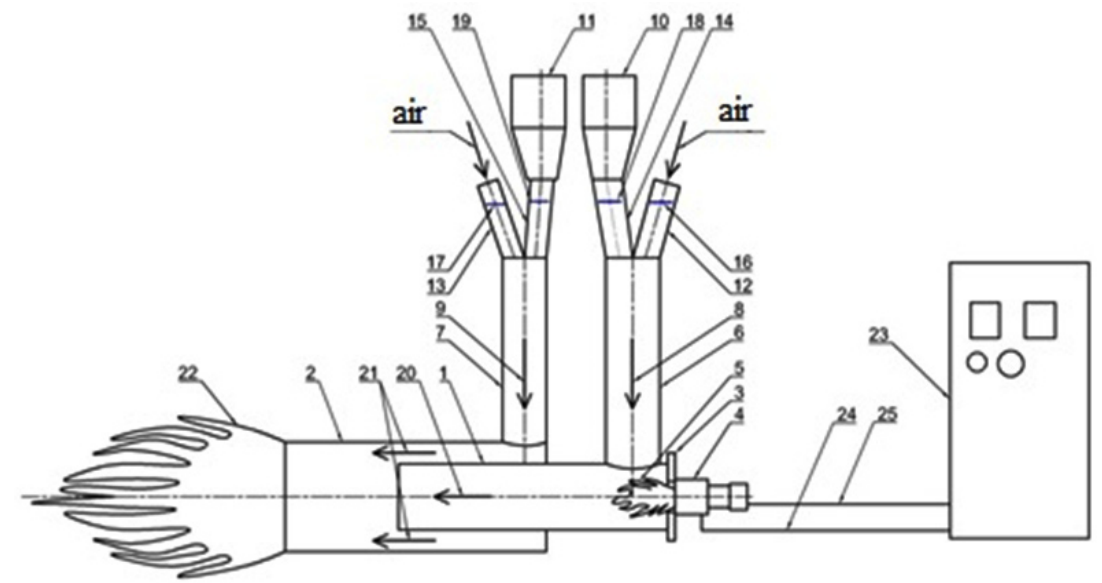

Fig. 1: The circuit schematic of the device and plasma pulverized-coal burner:

1- the first stage; 2 - the second stage; 3 - the fixing arrangement of the plasmatron; 4 - the electric arc plasmatron; 5 - the plasma torch; 6 - the air supply duct of the first stage; 7 - the air and fuel mixture supply duct of the second stage; 8,9 - the air and fuel mixture movement direction; 10, 11 - pulverized-coal bunkers; 12, 13 - air entrainment lines; 14, 15 - pulverized coal injection lines; 16, 17 - air shutters; 18, 19 - coal dumpers; 20 - air and fuel mixture movement on the first stage 21 - air and fuel mixture movement on the second stage; 22 - pulverized coal blend flame; 23 - power supply source; 24,25 - power cables

5 then is pulled to the outer tube 2. After that the pulverized coal in volume up to $80 \%$ from the total consumption through the burner is supplied by the air from the second feeder 11 also tangentially, and then is twisting spirally in the inner wall of the outer tube 2 of the second stage. Reacting with plasma prepared on the first stage air and fuel mixture, coal feed stream of the second stage partially is ignited and gasified. At the output from the pulverized-coal burner when mixing with the secondary air, all the coal feed stream is ignited to form the torch 22 .
Power control of the burner is carried out by changing the air and fuel mixture consumption to the first and second stages and by changing the power of the plasmatron. The current control is carried out in the range from 100 to $300 \mathrm{~A}$ and the voltage from 200 to $300 \mathrm{~V}$.

Figure 2 shows the operation of the plasma pulverized-coal burner in the mode of pulverized coal blend flame lighting. The prototypes for this burner and served are burners and the results of 
the investigations shown in the presented studies in detail2, 3 .

\section{THE RESULTS OF THE INVESTIGATIONS AND THEIR DISCUSSION}

At the initial stage of designing a complex of calculations is carried out through the programs "Terra" and "Plazmaugol ${ }^{4,5}$ to determine the expected range of the initial input parameters (temperature, coal and the air consumption, power of the plasmatron and other thermodynamic parameters).

The Tugnuiskiy coal was used as the fuel on the calculations and field trials with the following parameters shown in Table 1

The calculation under the program "Terra" allows to define theoretically required amount of the air. Thus for $100 \mathrm{~kg}$ of the coal there should be 130.27 $\mathrm{kg}$ of the air (which corresponds to the concentration of the pulverized coal $\mathrm{M}=0.62$ ). The calculation was made at the temperature range from 700 to $2500{ }^{\circ} \mathrm{C}$ which revealed an effective temperature range which is $1100-1200{ }^{\circ} \mathrm{C}$. The further increase of the plasmatron injected power to raise the temperature is ineffective. Because with significant injected power of the plasmatron the temperature of the mixture is increasing slightly. In practice it is observed the outer surface of the coal particles melting which violates the fuel components output.

As a result of theoretical researches under the program "Plasmaugol" it has been determined the plasmatron effective power which is $70-90 \mathrm{~kW}$ depending on the fuel consumption. When the initiation of the mixture $30 \%$ for the first stage and the activation with the help of the burning gas obtained for the first stage we can prepare the second part of the air and fuel mixture without a direct impact on the plasmatron. As a result of the calculations we obtained carbon oxide come on return from of the plasma pulverized-coal burner which is $612 \mathrm{~kg} / \mathrm{h}$, hydrogen - $11 \mathrm{~kg} / \mathrm{h}$, the degree of gasification is $65.5 \%$.

As a result of conducted analyses it was implemented the ignition of the coal feed stream for the first and second stages, both together and separately only for the first stage. On return from of the plasma pulverized-coal burner there was emerged a steady-state flame. The tests were conducted outside the boiler unit. The plasmatron with - system automation: coal-, air-, electricity- and water supply system was installed on the burner.

Today our team are well experienced with the development, design and creating of plasma fuel systems for coal and pulverized-coal fired boilers of a different power. So in 2002 there were performed assembly operations and adjustment work at Ulan-Ude Central Heating and Power Plant- $2^{6}$. The researches on the "The test program of upgraded plasma burners with low emissions of $\mathrm{NO}_{x}$ was carried out on the boiler unit No. 2 of Ulan-Ude Central Heating and Power Plant-2. The boiler unit TPE-185 of E-160-1,4-250kt type with the steamgenerating capacity of 160 tons of the steam per an hour and with six flat-plate burners.

The results of measurement tests showed up a direct dependence of the emissions content in

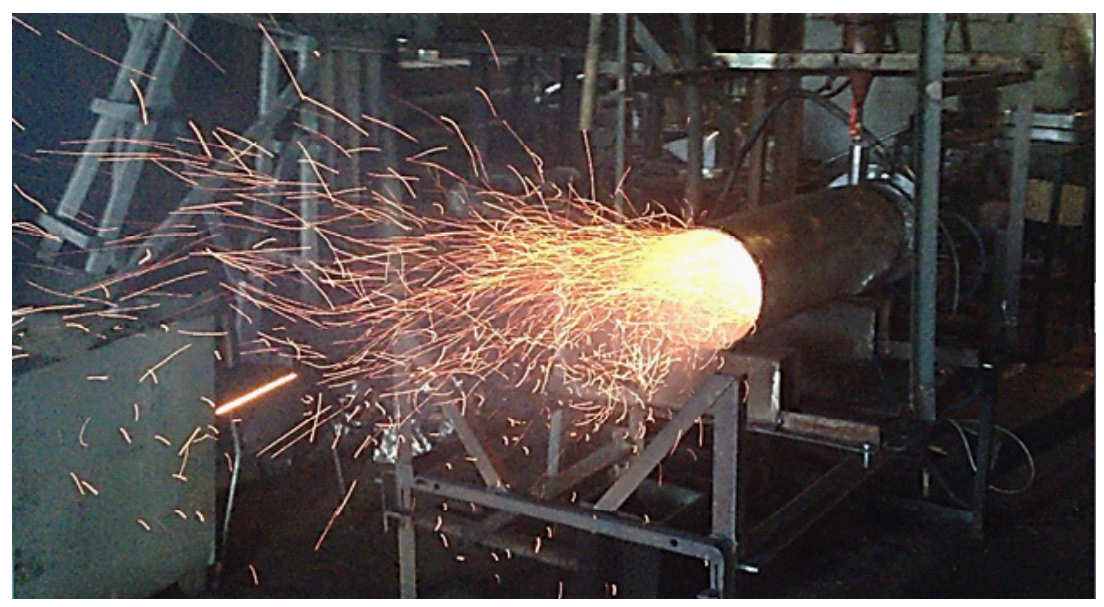

Fig. 2: Plasma pulverized-coal burner in operation 


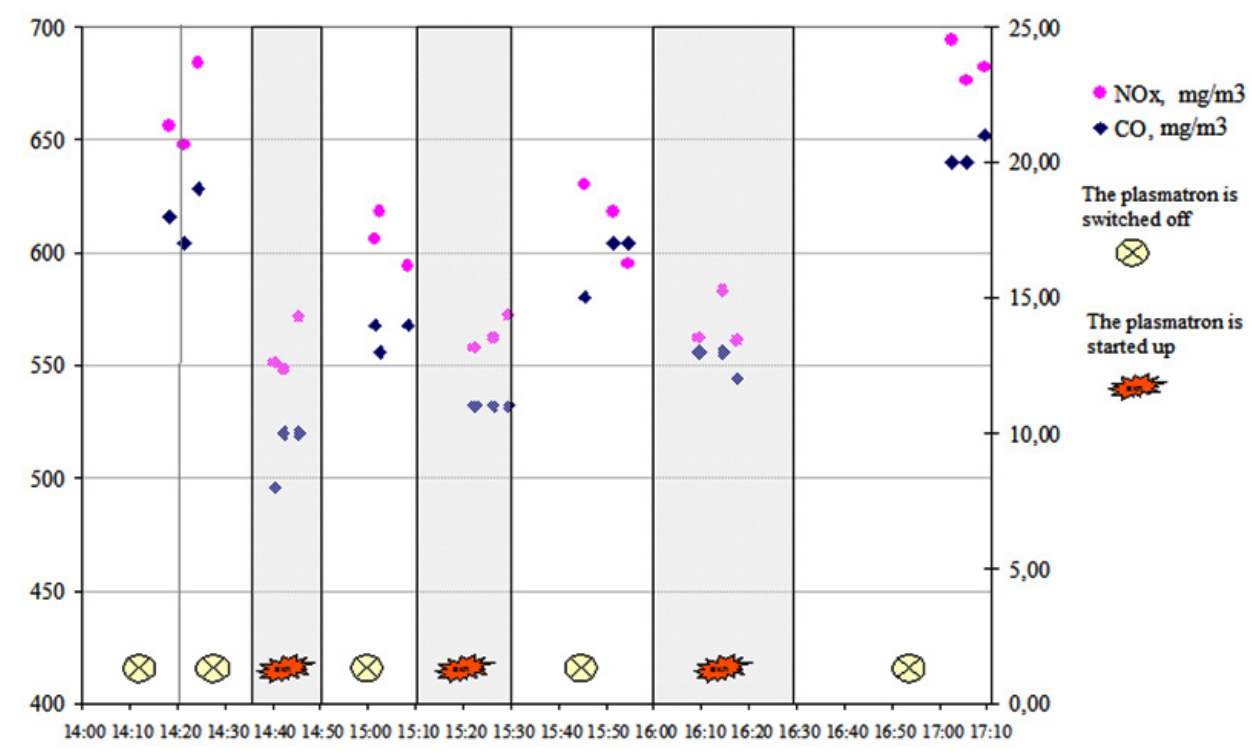

Fig. 3: The dynamics of the nitrogen oxides and carbon monoxide concentrations changes in the exhaust gases when tests of upgraded plasma burners were carried out

the exhaust gases and the amount of the unburned carbon loss that on whether plasma systems are included or not, it can be seen on the diagram (Figure 3). Especially there is represented a dependence of the $\mathrm{CO}$ content. The amount decreasing is $33 \%$ at an average (Table 2 ) which means the fuel underburning decreasing.

Reduction of the $\mathrm{NO}_{\mathrm{x}}$ emissions was $10.2 \%$ at an average. Such result is very significant if we take into consideration that only $25 \%$ of the pulverized coal flow through topping plasma burners (2 nozzles from 8 nozzles are operated). However the increase of the oxygen concentration in the exhaust gases increased up to $2.2 \%$ at an average that occurs probably due to the decrease of the fuel nitrogen formation. The exhaust gases temperature remained at the level of $128-131^{\circ} \mathrm{C}$. When plasma burners were started up the content of fuel remnants was decreasing in the ash from $14.2 \%$ to $3.4 \%$, in the slag from $20.9 \%$ to $14.8 \%$. After the plasmatrons were switched off in 15 minutes the content of fuel remnants in the ash was $4,8 \%$, in the slag was $7,8 \%$

\section{CONCLUSION}

During the tests the plasma burner effectiveness is proved for kindling a boiler and inflammation pulverized coal blend flame. Kindling and inflammation were carried out in the standard operating mode but mazut is not supplied to the burner.

As a result of theoretical and experimental investigations of the plasma pulverized-coal burner comparing it with known plasma systems it stands to mention the following advantages of the burner:

1. simplified construction (there isn't a scroll and the flow swirl is achieved by using petals installed inside the tube at the dust flow entrance);

2. inside the burner coal plasma-thermal pretreatment is implemented with an adjustment coefficient of the air excess in supplied air and fuel mixture stream which improve the process of the electric chemical fuel preparation and to install this burner to any fuel systems of pulverized-coal fired boilers operated in power plants.

3. So the process of the electric chemical fuel preparation is divided into two processes: in the inner tube it occurs directly this process itself and in the intertubular space at the beginning it occurs thermal fuel preparation and only then the it occurs mixing of the two flows with followed electric chemical preparation of the main dust flow. 
4. The inner tube production from an ordinary steel makes cheaper a production and the cost of such burner.

5. The plasma pulverized-coal burner construction allows processes of air supply control, pulverized coal control, temperature control and control of the length of the pulverized coal blend flame in the boiler furnace operate completely automatically.

All of the above-mentioned make it possible to state that the developed plasma pulverized-coal burner is an effective tool to ignite the pulverized coal blend flame not using mazut and can be used in pulverized-coal fired boilers of a medium and high power.

\section{REFERENCES}

1. Buyantuev S. L.; Shishulkin S.U.; Zonkhoev G.B.; Starinsky I.V.; Khmelev A.B. The plasma pulverized-coal burner. The patent of the RF No. 2543648 as of January 10, 2014 published on March 10, 2015, report .No. 7

2. Buyantuev, S.L.; Zonkhoev, G.B.; Shishulkin, S.Yu.; Starinsky, I.V. The plasma thermal processing and preparation of coals for combustion in the energy and the housing and public utilities. Ulan-Ude: publishing house ESSTU, b, . 164

3. Buyantuev, S.L.; Shishulkin, S.Yu. The plasma thermal processing and preparation of coals for combustion. Ulan-Ude: publishing house ESSTU, 2003, 176.

4. Zonkhoev, G.B. Improvement of the fuel use effectiveness and environmental specifications of power plants pulverized-coal fired boilers using modified plasma burner, PhD thesis, ESSTU, Ulan-Ude, 2011.

5. Shishulkin, S.Yu. The plasma thermal pretreatment of solid fuels for burning based on the modular two-stage unit, PhD thesis, ESSTU, Ulan-Ude, b.

6. Buyantuev, S.L.; Elisafenko, A.V.; Legostaev, S.M.; others. The using of plasma pulverizedcoal burner for pollutant emissions reductions and technical and economic index increasing of a bolier unit such as TPE-185 of the UlanUde Central Heating and Power Plant-2. The energy industry; 2009, 3, 13-15. 